\title{
Spatial and temporal variability in coccolithophore abundance and distribution in the NW Iberian coastal upwelling system
}

\author{
Blanca Ausín $^{1,2}$, Diana Zúñiga ${ }^{3,4,5}$, Jose A. Flores ${ }^{1}$, Catarina Cavaleiro ${ }^{4,5,6}$, María Froján ${ }^{3}$, \\ Nicolás Villacieros-Robineau ${ }^{7}$, Fernando Alonso-Pérez ${ }^{3}$, Belén Arbones ${ }^{3}$, Celia Santos $^{4,5,6,8}$, Francisco de la Granda ${ }^{9}$, \\ Carmen G. Castro ${ }^{3}$, Fátima Abrantes ${ }^{4,5}$, Timothy I. Eglinton ${ }^{2}$, and Emilia Salgueiro ${ }^{4,5}$ \\ ${ }^{1}$ Departamento de Geología, Universidad de Salamanca, Salamanca, 37008, Spain \\ ${ }^{2}$ Department of Earth Sciences, ETH Zurich, Zurich, 8092, Switzerland \\ ${ }^{3}$ Instituto de Investigaciones Marinas (IIM), Consejo Superior de Investigaciones Científicas (CSIC), Vigo, 36208, Spain \\ ${ }^{4}$ Div. Geologia e Georecursos Marinhos, Instituto Português do Mar e da Atmosfera (IPMA), Lisbon, 1749-077, Portugal \\ ${ }^{5}$ CCMAR - Centre of Marine Sciences, Universidade do Algarve, Faro, 8005-139, Portugal \\ ${ }^{6}$ MARUM, Centre for Marine Environmental Sciences, Bremen, 28359, Germany \\ ${ }^{7}$ Laboratoire d'Oceanographie et du Clima, Université Pierre et Marie Curie, Paris, 75005, France \\ ${ }^{8}$ Alfred Wegener Institute, Helmholtz Centre for Polar and Marine Sciences, Bremerhaven, 27570, Germany \\ ${ }^{9}$ Federal Maritime and Hydrographic Agency, Hamburg, 20359, Germany
}

Correspondence: Blanca Ausín (blanca.ausin@erdw.ethz.ch)

Received: 6 June 2017 - Discussion started: 3 July 2017

Revised: 4 October 2017 - Accepted: 21 November 2017 - Published: 11 January 2018

\begin{abstract}
A systematic investigation of the spatial and temporal variability in coccolithophore abundance and distribution through the water column of the NW Iberian coastal upwelling system was performed. From July 2011 to June 2012, monthly sampling at various water depths was conducted at two parallel stations located at $42^{\circ} \mathrm{N}$.

Total coccosphere abundance was higher at the outer-shelf station, where warmer, nutrient-depleted waters favoured coccolithophore rather than phytoplanktonic diatom blooms, which are known to dominate the inner-shelf location.

In seasonal terms, higher coccosphere and coccolith abundances were registered at both stations during upwelling seasons, coinciding with high irradiance levels. This was typically in conjunction with stratified, nutrient-poor conditions (i.e. relaxing upwelling conditions). However, it also occurred during some upwelling events of colder, nutrient-rich subsurface waters onto the continental shelf. Minimum abundances were generally found during downwelling periods, with unexpectedly high coccolith abundance registered in subsurface waters at the inner-shelf station. This finding can only be explained if strong storms during these downwelling periods favoured resuspension processes, thus remobilizing deposited coccoliths from surface sediments, and hence ham-
\end{abstract}

pering the identification of autochthonous coccolithophore community structure.

At both locations, the major coccolithophore assemblages were dominated by Emiliania huxleyi, small Gephyrocapsa group, Gephyrocapsa oceanica, Florisphaera profunda, Syracosphaera spp., Coronosphaera mediterranea, and Calcidiscus leptoporus. Ecological preferences of the different taxa were assessed by exploring the relationships between environmental conditions and temporal and vertical variability in coccosphere abundance. These findings provide relevant information for the use of fossil coccolith assemblages in marine sediment records, in order to infer past environmental conditions, of particular importance for Paleoceanography. Both E. huxleyi and the small Gephyrocapsa group are proposed as proxies for the upwelling regime with a distinct affinity for different stages of the upwelling event: E. huxleyi was associated with warmer, nutrient-poor and more stable water column (i.e. upwelling relaxation stage) while the small Gephyrocapsa group was linked to colder waters and higher nutrient availability (i.e. early stages of the upwelling event), similarly to $G$. oceanica. Conversely, $F$. profunda is suggested as a proxy for the downwelling regime and low-productivity conditions. The assemblage composed 
by Syracosphaera pulchra, Coronosphaera mediterranea, and Rhabdosphaera clavigera may be a useful indicator of the presence of subtropical waters conveyed northward by the Iberian Poleward Current. Finally, C. leptoporus is proposed as an indicator of warmer, saltier, and oligotrophic waters during the downwelling/winter regime.

\section{Introduction}

Coccolithophores are a group of marine calcifying phytoplankton with worldwide distribution in modern oceans. These microscopic algae are one of the main contributors to biogenic sediments by the production of calcite plates, named coccoliths, which form their outer shell, the coccosphere. Environmental conditions within the photic zone determine coccolithophore productivity, assemblage composition, and spatial distribution. Thus, fossil coccolith records recovered from sedimentary archives are extensively used to reconstruct past variability of surface water dynamics (e.g. McIntyre, 1967), nutricline position (e.g. Molfino and McIntyre, 1990), primary productivity (e.g. Beaufort et al., 1997; Beaufort and Heussner, 2001), and $\mathrm{CO}_{2}$ (e.g. Stoll et al., 2002), among others. In the modern ocean, different coccolithophore assemblages are broadly distributed according to five biogeographic regions, each of them characterized by specific water masses (McIntyre and Bé, 1967). However, local processes such as eddies, jets and upwelling plumes can determine a much wider variety of assemblages whose ecology and relationships with the local environmental conditions cannot be extrapolated elsewhere (Baumann et al., 2005). Hence, extensive understanding on the regional ecology of coccolithophores in modern ocean waters is crucial to correctly interpret abundance of calcareous nannofossils in marine sediment records to infer environmental conditions and productivity variations in the past.

The Atlantic Iberian Margin is located at the northern part of the Canary Eastern Boundary Upwelling Ecosystem, one of the four major coastal upwelling systems of the world's oceans (Fraga, 1981; Fiúza, 1983; Arístegui et al., 2009). It is a preferred location for paleoceanographic investigations due to high sedimentation rates, which allow studying marine records at sub-millennial scale. Furthermore, the combination of fluvial inflow from several rivers and a narrow continental shelf allows for the study of land-ocean interaction processes (Sánchez-Goñi et al., 1999, 2002). Fossil coccolith records are being extensively used for climatic reconstructions along the western Iberian Margin (Parente et al., 2004; Flores et al., 2010; Incarbona et al., 2010; Amore et al., 2012; Palumbo et al., 2013). However, the few existing studies characterizing living coccolithophore community, distribution, abundance, and ecology in the water column are mostly based on central and southern areas (Cachão and Moita, 2000; Cachão et al., 2000; Ferreira and Cachão,
2005; Silva et al., 2008; Moita et al., 2010; Guerreiro et al., 2013; Guerreiro et al., 2014), being scarce for northern locations (Abrantes and Moita, 1999; Moita, 2001). In this context, we present a year-long data set of coccospheres and free coccoliths based on monthly sampling at several depths at two different stations (one on the inner shelf and one on the outer shelf) across the NW Iberian Margin. This study aims to characterize spatial and temporal variability in coccolithophore abundance as a response to local and regional environmental processes. These findings will further contribute to infer different paleoceanographic patterns of the NW Iberian coastal upwelling system by analysing fossil coccolith assemblages.

\section{Oceanographic setting}

The sampling sites (RAIA and CALIBERIA stations; Fig. 1) were located in the NW Iberian coastal upwelling system. Large-scale oceanographic processes in this area are marked by a strong seasonal pattern, mostly determined by the regional atmospheric circulation. Generally, the semipermanent Azores High displaces northward during springsummer seasons (April to September/October), promoting northerly winds blowing over the continental shelf and inducing offshore Ekman transport (Fiúza, 1983; Alvarez et al., 2011). Accordingly, upwelling of subsurface, cold, and nutrient-rich Eastern North Atlantic Central Water (ENACW) occurs, leading to high primary production (Fraga, 1981; Tenore et al., 1995; Figueiras et al., 2002). In contrast, during autumn and winter (October to March/April), the Azores High weakens and migrates southward while the Icelandic Low intensifies. In this context, southerly wind regime is accompanied by downwelling favourable conditions and a consequent decrease in primary productivity. Strong southwesterly winds at this time might also induce highly energetic storms that can lead to wavedriven mobilization of fine sediments from mid-shelf depths (Dias et al., 2002a; Vitorino et al., 2002; Oberle et al., 2014). During these periods, fluvial discharges from Minho and Douro rivers, located south, can contribute terrestrial sediments to the study area (Dias et al., 2002a, b; Zúñiga et al., 2016). Oceanographically, from October to January, the region is affected by the presence of the Iberian Poleward Current (IPC), which flows northwards and transports relatively warm, saline and nutrient-poor waters to our study site (Haynes and Barton, 1990; Castro et al., 1997; ÁlvarezSalgado et al., 2003, and references therein; Peliz et al., 2005; Relvas et al., 2007). Later on, the winter cooling in FebruaryMarch favours a decrease in temperature that promotes a well homogenized mixed layer of cold and nutrient-rich waters (Castro et al., 1997; Álvarez-Salgado et al., 2003). 


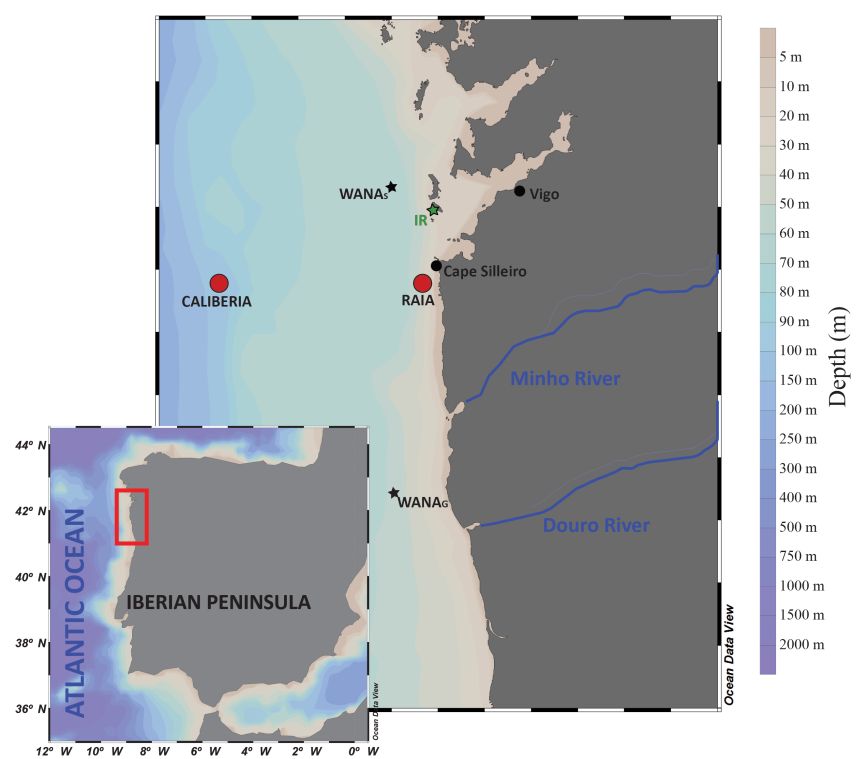

Figure 1. Map of the NW Iberian Margin showing CALIBERIA and RAIA stations. Location of Cíes meteorological station (IR, in green), and WANA hindcast reanalysis points WANA $_{S}$ and WANA $_{G}$ (black stars) from which irradiance and wave data were respectively obtained (Zúñiga et al., 2016).

\section{Material and methods}

\subsection{Sea water samples collection and environmental data}

Sea water samples were collected at two stations: one close to the coast ( $4.1 \mathrm{~km}$ from the coastline) located off Cabo Silleiro (RAIA station; $42^{\circ} 05^{\prime} \mathrm{N} ; 8^{\circ} 56^{\prime} \mathrm{W}, 75 \mathrm{~m}$ water depth), and one further offshore ( $52.8 \mathrm{~km}$ from the coastline) located at the outer continental shelf (CALIBERIA station; $42^{\circ} 05^{\prime} \mathrm{N}$, $9^{\circ} 23^{\prime} \mathrm{W} ; 350 \mathrm{~m}$ water depth). Continuous CTD-SBE911 profiles were recorded at both stations to measure temperature and salinity through the water column. Sampling was conducted monthly on board R/V Mytilus from July 2011 to June 2012 (except August and April). Water column samples were obtained from selective rosette $10 \mathrm{~L}$ PVC Niskin bottles at 10,50 , and $70 \mathrm{~m}$ water depth at RAIA station and at 10 , 50, 100, 150, 250, and $300 \mathrm{~m}$ water depth at CALIBERIA sampling site. Seawater samples were used for analyses of coccolithophore and diatom assemblages, and determination of both inorganic nutrients $\left(\mathrm{NO}_{3}^{-}, \mathrm{HPO}_{4}^{2-}, \mathrm{Si}(\mathrm{OH})_{4}\right)$ and chlorophyll $a$ (Chl $a$ ) concentrations. For coccolithophore analyses, a seawater volume between 2 and $5 \mathrm{~L}$ was filtered through a cellulose filter of $0.45 \mu \mathrm{m}$ pore size by using a vacuum pump. Then, each filter was stored in plastic Petri dishes and dried. Additionally, diatom abundance was determined at $5 \mathrm{~m}$ water depth by depositing between 10 and $50 \mathrm{~mL}$ in composite sedimentation chambers for observation through an inverted microscope. Sample preparation and analyses for diatom abundance determination are described in detail in Zúñiga et al. (2017). Inorganic nutrients were measured by segmented flow analysis with Futura-Alliances autoanalysers following Hansen and Grassoff (1983) and pigment extract fluorescence was performed to estimate final $\mathrm{Chl} a$ concentrations with a Turner Designs fluorometer calibrated using pure Chl $a$ (Sigma) (for details, see Zúñiga et al., 2016).

Data of regional irradiance, wave height, Bakun's upwelling index, and river discharge from July 2011 to June 2012 presented in Zúñiga et al. $(2016,2017)$ were used in this study to evaluate the influence of physical forcing on coccosphere and coccolith abundance and variability (Figs. 2a-d).

\subsection{Coccolithophore analyses}

A random piece of filter was cut and mounted on a slide and rendered transparent with a few drops of immersion oil. General preservation of coccoliths and coccospheres was determined in every sample based on visual criteria as barren, very poor, poor, moderate, and good following Flores and Marino (2002), and converted into a numerical scale from 0 for barren samples to 4 for good general preservation. Excluding barren samples, at least 500 coccoliths per sample and all the coccospheres (i.e. coccolithophores) encountered during this process (ranging from 100 to 300) were counted and identified using a polarized light microscope at $\times 1000$ magnification. Consequently, species with a relative abundance $>2 \%$ could be detected with a confidence limit of $99.5 \%$ for the coccolith data set, and within a confidence limit range of 90-99.5\% for the coccosphere data set (Fatela and Taborda, 2002).

Following Cachão and Oliveira (2000), data sets of free coccoliths and coccospheres were studied separately. The relative abundance $(\%)$ and the absolute abundance (given in coccoliths $\mathrm{L}^{-1}$ and cells $\mathrm{L}^{-1}$, for coccoliths and coccospheres respectively) of each species were calculated for all samples. Absolute abundance $(A)$ was calculated by Eq. (1):

$A=(C a) /(N V n)$,

where $C$ is the number of coccoliths or coccospheres, $N$ is the number of visual fields considered; $V$ is the volume of the filtered water $(\mathrm{mL}) ; a$ is the area of the filter; and $n$ is the area per visual field.

Species were classified following Young et al. (2003). Gephyrocapsa specimens smaller than $3 \mu \mathrm{m}$ (G. aperta and G. ericsonii) were lumped together as "small Gephyrocapsa group" (Flores et al., 1999). Distinct morphotypes of the species Coccolithus pelagicus were classified according to coccolith size criteria following Parente et al. (2004) $-C$. pelagicus ssp. braarudii, $>10 \mu \mathrm{m} ;$ C. pelagicus ssp. pelagicus, $<10 \mu \mathrm{m}$. Non-extant species of calcareous nannofossils were counted as "reworked specimens". These belong to older stratigraphic levels and have generally been affected by resuspension and secondary transport by rivers or deep 
$\begin{array}{ll}\text { (a) Irradiance }\left(10 \mathrm{~kJ} \mathrm{~m}^{-2} \text { day }^{-1}\right) & \text { (b) Wave height }(\mathrm{m})\end{array}$

(c) Upwelling index $\left(\mathrm{m}^{3} \mathrm{~s}^{-1} \mathrm{~km}^{-1}\right)$ (d) River discharge $\left(\mathrm{m}^{3} \mathrm{~s}^{-1}\right)$
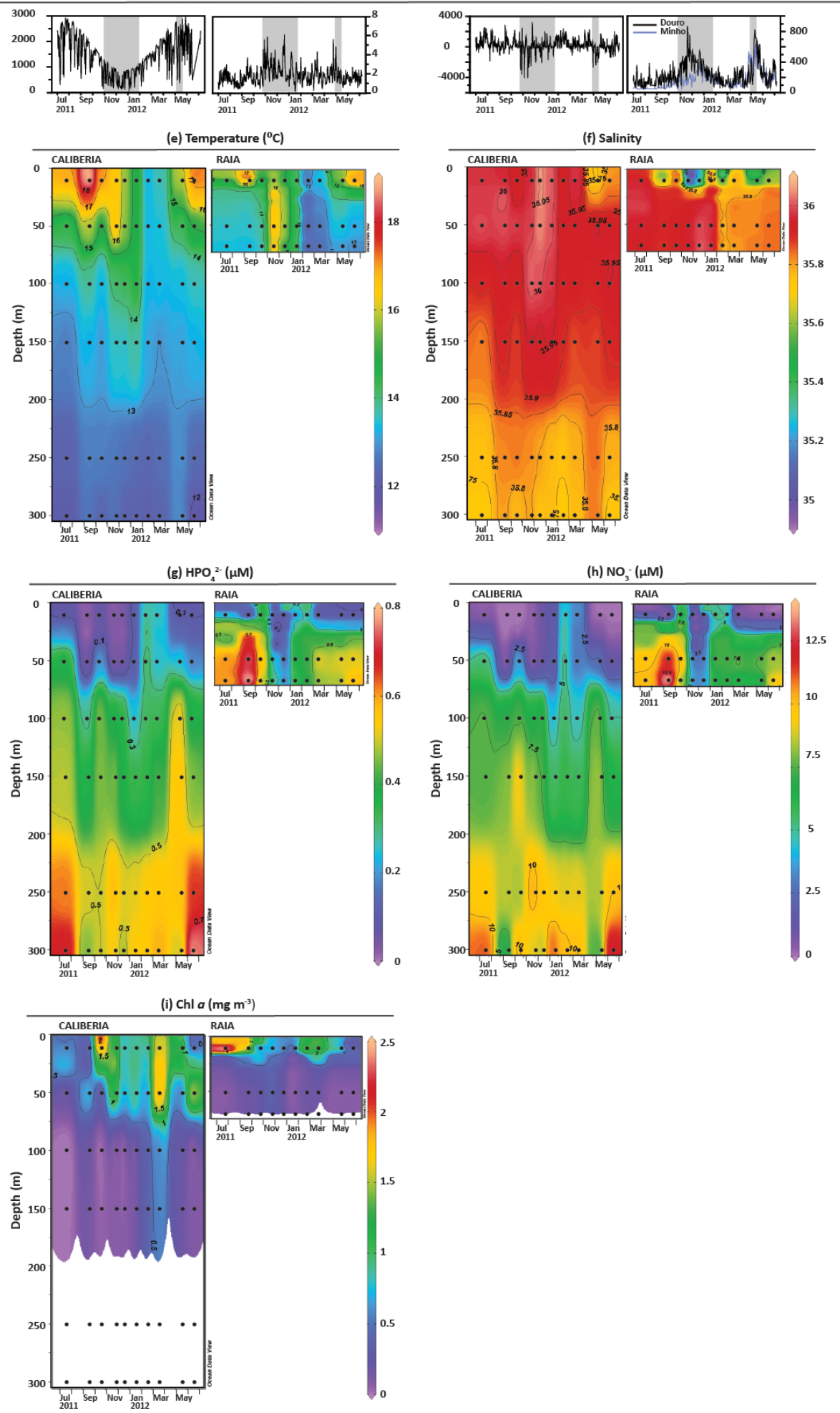

Figure 2. Environmental conditions for the studied period. Available data on (a) irradiance, (b) wave height, (c) Bakun's upwelling index, and (d) discharges by Minho (blue) and Douro (black) rivers (Zúñiga et al., 2016, 2017). Grey and white bars represent downwelling and upwelling periods, respectively, based on upwelling index and biogeochemical data presented and interpreted in Zúñiga et al. (2016, 2017). Temporal and vertical distribution of (e) temperature, (f) salinity, (g) $\mathrm{HPO}_{4}^{2-}$, (h) $\mathrm{NO}_{3}^{-}$, and (i) Chl $a$ at CALIBERIA and RAIA stations. Black dots represent collected water samples for coccolithophore analyses. 
currents (Ferreira et al., 2008), indicating an allochthonous environmental signal.

\subsection{Statistical analysis}

Evaluation of ecological similarities among coccolithophore species and their relationship with the environmental conditions was performed using a canonical correspondence analysis (CCA). The analysis was only implemented for the CALIBERIA station data set given that RAIA station was affected by resuspension of coccoliths from the underlying sediments, which may also have affected coccolithophore distribution in the water column (see Sect. 5.1.1). Ecological relationships were assessed as a function of the distance among the species and the variables on an ordination graph. Akaike's information criterion (AIC) was applied in prior ordination analysis to identify the model with the minimum number of environmental variables that, being statistically significant, explained the maximum inertia (i.e. variance in the coccosphere data). Initially, 11 explanatory variables were considered: temperature, salinity, $\mathrm{NO}_{3}^{-}, \mathrm{HPO}_{4}^{2-}$, $\mathrm{Si}(\mathrm{OH})_{4}$, particulate organic carbon (POC), irradiance, wave height, Bakun's upwelling index, and both Minho River and Douro river discharges. For each variable, three different temporal resolutions were considered, averaging the available data corresponding to: the sampling date, the sampling day plus 2 days before, and the sampling day plus 4 days before. Barren samples were excluded from the ordination analyses and only major coccolithophore species (those with a relative abundance $>2 \%$ in at least two samples and whose confidence limit of detection is $>90 \%$ in this study) were considered. After significant variables were identified via backward procedure, CCA was performed. Ordinations were performed with the "vegan" package v.2.3. (Oksanen et al., 2016) for R (R Core Team, 2015).

\section{Results}

\subsection{Environmental conditions and associated physical processes during sampling}

Environmental conditions at RAIA station from November 2008 to June 2012 have been previously assessed in detail by Zúñiga et al. (2016). For the period considered in this study, northerly winds occurred from July to November 2011, and from February to May/June of 2012, with the water column being characterized by the upwelling of cold, more saline and nutrient-rich ENACW on the NW Iberian Margin, principally at the inner continental shelf where the presence of these upwelled waters at shallower depths were strongly linked to Chl $a$ maxima (Fig. 2i). On the other hand, from November to January, and part of May, downwelling favourable winds and low irradiance levels were also accompanied by high wave heights and consecutive Minho and Douro river discharges, as shown by the presence of less saline water lenses at the surface layer (Fig. 2d and f). From November to December, anomalously warmer $\left(14-16^{\circ} \mathrm{C}\right)$, saltier (>35.8), and nutrient-poor $\left(\sim 0.1 \mu \mathrm{M}\right.$ of $\mathrm{HPO}_{4}^{2-}$ and $<2.5 \mu \mathrm{M}$ of $\mathrm{NO}_{3}^{-}$) waters conveyed by the IPC were distinguished (Figs. 2e-h). Finally, during February, winter mixing conditions were also detected with the water column being homogeneously characterized by colder waters $\left(<13^{\circ} \mathrm{C}\right)$ with salinity values $<35.8$ and higher nutrient concentration $\left(0.3-0.5 \mu \mathrm{M}\right.$ of $\mathrm{HPO}_{4}^{2-}$ and $2.5-5 \mu \mathrm{M}$ of $\left.\mathrm{NO}_{3}^{-}\right)$. The outer-shelf station was generally characterized by warmer and more nutrient-poor waters. Yet the temperature and nutrient distribution in the upper layer revealed similar seasonal patterns in both stations, and the influence of less saline lenses from river discharges was also observed at the outershelf station in May (Figs. 2e-h). Chl $a$ concentrations were of the same order in both stations, although its temporal variability differed markedly and coupling between stations only occurred from March to May (Fig. 2i).

\subsection{Diatom abundance}

Diatom abundances at $5 \mathrm{~m}$ water depth at the RAIA innershelf station have been previously discussed by Zúñiga et al. (2017). These peak during the upwelling periods and reach a maximum of $\sim 1 \times 10^{6}$ cells $L^{-1}$ in September 2011 (Fig. 3a). At the CALIBERIA outer-shelf station, diatom abundances were much lower, reaching a maximum of $\sim 200 \times 10^{3}$ cells $\mathrm{L}^{-1}$ during the second upwelling period (March-June 2012).

\subsection{Total coccosphere and coccolith absolute abundances}

In general, coccosphere and coccolith preservation varied from moderate to good (Fig. 3b), allowing identification of nearly all (moderate preservation) or all specimens (good preservation) at species level.

\subsubsection{Coccolithophore standing crops}

At RAIA inner-shelf station, coccosphere absolute abundance was generally very low, except during March and June 2012 at $10 \mathrm{~m}$ water depth reaching $1 \times 10^{5}$ and $2 \times 10^{5}$ cells $^{-1}$, respectively (Fig. 3c).

At CALIBERIA outer-shelf station, coccosphere absolute abundance ranged between 0 and $3 \times 10^{5}$ cells $\mathrm{L}^{-1}$ (Fig. $3 \mathrm{c}$ ). Higher cell densities occurred during spring and summer months between 10 and $50 \mathrm{~m}$ depth, reaching maximum numbers in March 2012 (Fig. 3c). In contrast, coccosphere abundances dropped to minimum levels during winter.

\subsubsection{Coccolith absolute abundance}

At RAIA inner-shelf station, coccolith absolute abundance ranged between 0 and $6 \times 10^{7}$ coccoliths $\mathrm{L}^{-1}$ (Fig. 3d). Minimum values were registered between July and October 

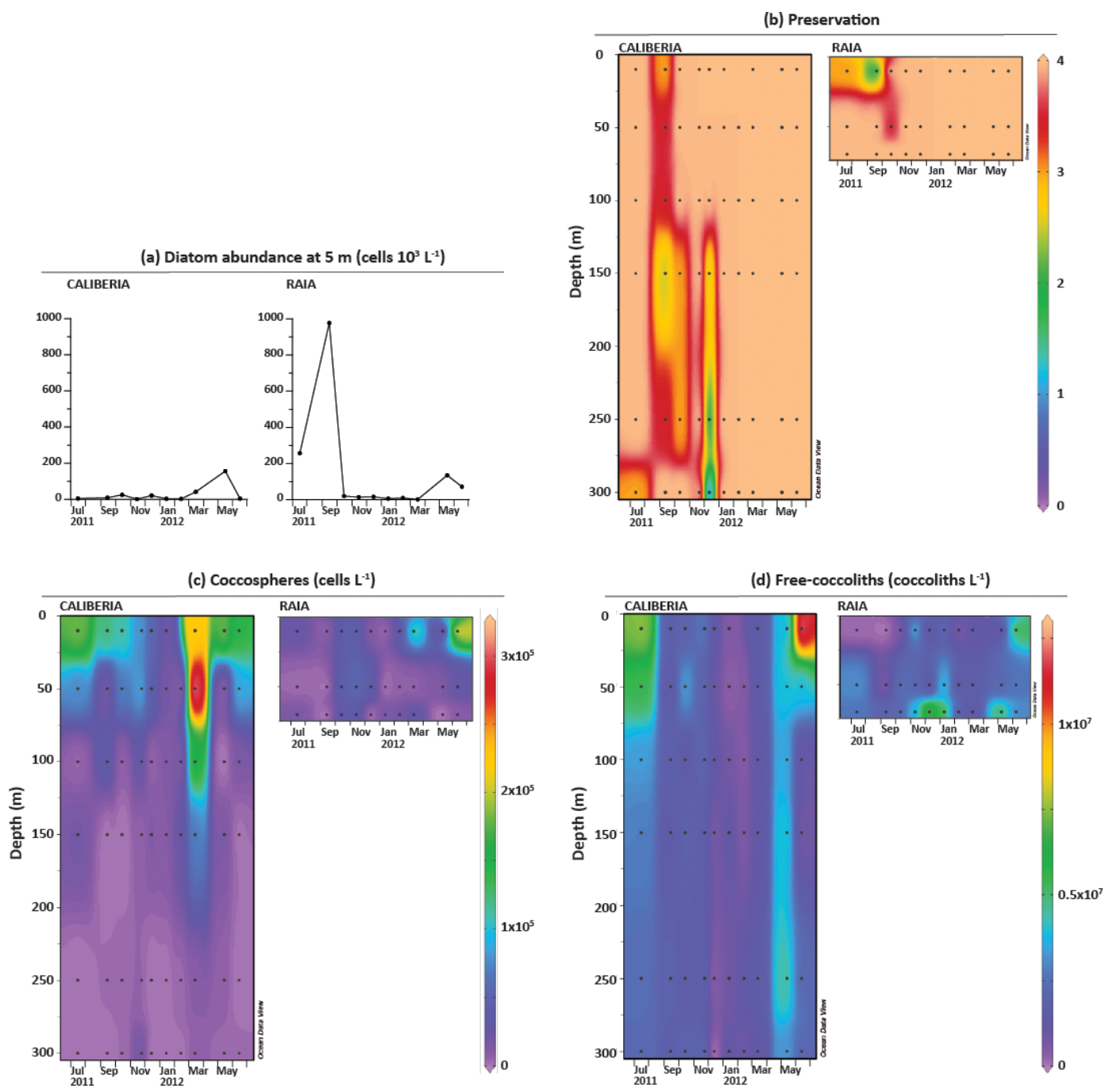

Figure 3. (a) Diatom absolute abundance (cells $10^{3} \mathrm{~L}^{-1}$ ) at $5 \mathrm{~m}$ at CALIBERIA (this study) and RAIA (Zúñiga et al., 2017). (b) Preservation of coccolithophore samples; and temporal and vertical distribution of the total number of (c) coccospheres (cells $\left.\mathrm{L}^{-1}\right)$ and (d) free coccoliths (coccoliths $\mathrm{L}^{-1}$ ), at CALIBERIA and RAIA stations. Black dots represent the sampling month and depth. See text for conversion of numeric values in colour bar to the corresponding qualitative preservation.

2011 and February-May 2012 at $10 \mathrm{~m}$. Coccolith minima in September 2011 coincide with poor sample preservation but also maxima in diatom abundance. Maximum values were observed in December 2011 and January 2012 at $70 \mathrm{~m}$, and June 2012 at $10 \mathrm{~m}$.

At CALIBERIA outer-shelf station, coccolith absolute abundance ranged between 0 and $1.25 \times 10^{7}$ coccoliths $\mathrm{L}^{-1}$ (Fig. 3d) with maximum abundances in July $2011\left(\sim 7.5 \times 10^{6}\right.$ coccoliths $\left.\mathrm{L}^{-1}\right)$ and June 2012 $\left(\sim 1.25 \times 10^{7}\right.$ coccoliths $\left.\mathrm{L}^{-1}\right)$ at $10 \mathrm{~m}$ water depth, decreasing gradually through the fall season (October and November 2011), and dropping to minimum values in winter (December 2011-March 2012).

Distributions of total both coccosphere and coccolith abundances within each station are in general agreement.
One exception is found in March 2012 at both stations, when the maximum of coccospheres does not have a counterpart in the coccolith signals. Another exception to this general agreement occurs from November to January at RAIA station, when higher coccolith abundances at $70 \mathrm{~m}$ depth are not reflected by the coccosphere abundance.

\subsection{Major assemblage composition}

Assemblages of both forms, coccospheres and coccoliths, showed the same major composition at both stations (Figs. 4 and 5). E. huxleyi was the dominant species, being present through the whole studied period, and achieving percentages higher than $90 \%$ of both forms during the upwelling regime. The second major taxa was the small Gephyrocapsa group, which reached its highest relative abundance from February 
(a) RAIA-Coccospheres [\%]

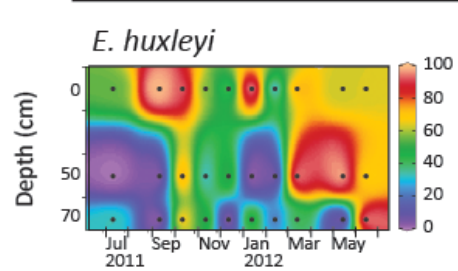

G. oceanica

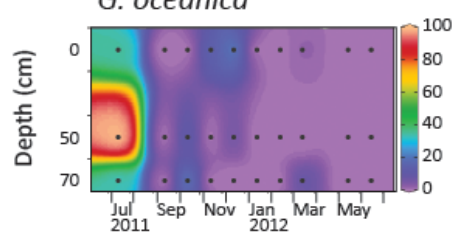

Syracosphaera spp.

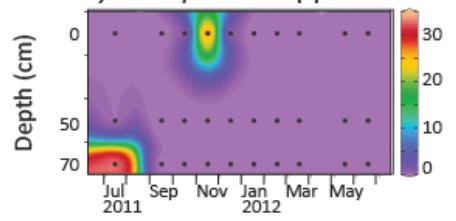

C. leptoporus

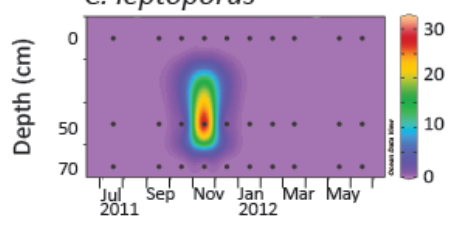

(b) RAIA-Coccoliths [\%]

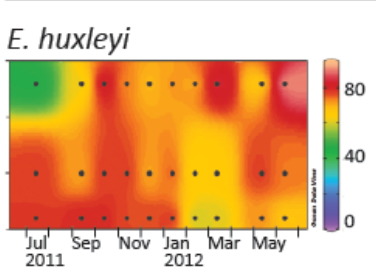

G. oceanica

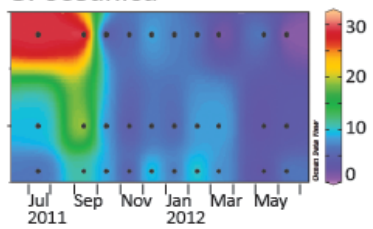

Syracosphaera spp.

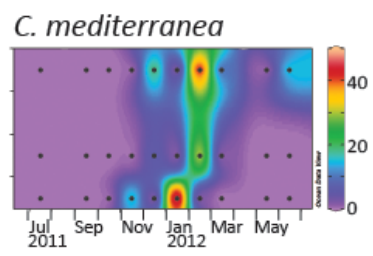

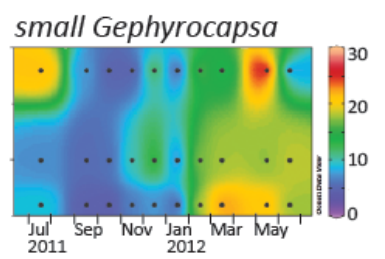

F. profunda

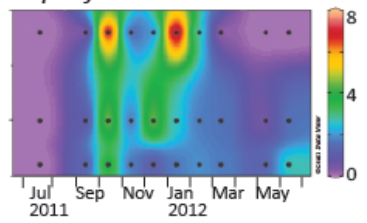

C. mediterranea

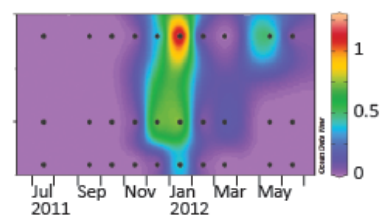

R. clavigera

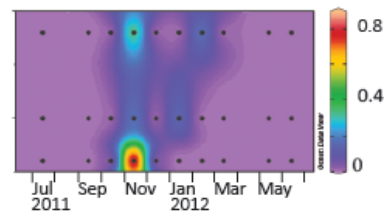

C. leptoporus

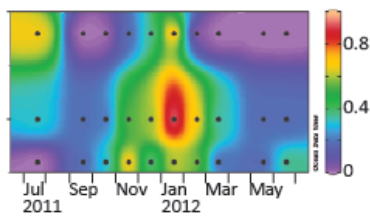

Reworked coccoliths

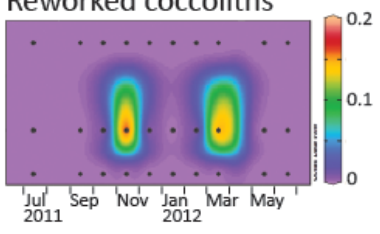

Figure 4. Relative abundance (\%) of major species of coccospheres (a) and coccoliths (b) in RAIA station. Black dots represent the sampling month and depth. Note that each colour bar has been scaled to the maximum and minimum values of its corresponding species.

to May at both stations. Other major species were Gephyrocapsa oceanica, Florisphaera profunda, Syracosphaera spp. (mainly S. pulchra), Coronosphaera mediterranea, Calcidiscus leptoporus, and, to a small extent, Rhabdosphaera clavigera in only two samples of CALIBERIA station. Reworked coccolith specimens did not exceed $0.3 \%$ of relative abundance for any sample (Figs. 4 and 5). Other minor species and taxa identified and counted are listed in Appendix A.

\subsection{Inner-shelf temporal variability in species absolute abundance}

At the RAIA inner-shelf station, E. huxleyi ranged between 0 and $5 \times 10^{5}$ cells L $^{-1}$, being more abundant in March and June 2012 at $10 \mathrm{~m}$, similarly to small Gephyrocapsa group (up to $\sim 4 \times 10^{4}$ cells L ${ }^{-1}$ ) (Fig. 6). G. oceanica (up to $\sim 8 \times 10^{3}$ cells $\mathrm{L}^{-1}$ ) reached its maximum in July at $10 \mathrm{~m}$ depth, but it abounded at and below $50 \mathrm{~m}$ water depth. F. profunda was present in October at all depths, reaching its highest density $\left(\sim 5 \times 10^{3}\right.$ cells $\left.\mathrm{L}^{-1}\right)$ at $50 \mathrm{~m}$. Syracosphaera spp. and $C$. leptoporus were present in November, the former at $10\left(1 \times 10^{3}\right.$ cells $\left.\mathrm{L}^{-1}\right)$ and the latter at $50 \mathrm{~m}$ water depth $\left(1.5 \times 10^{4}\right.$ cells L $\left.^{-1}\right)$ (Fig. 6). C. mediterranea shows higher density $\left(3 \times 10^{4}\right.$ cells $\left.\mathrm{L}^{-1}\right)$ in June 2012 at $10 \mathrm{~m}$ and lower abundances in February and March. Coccolith and coccosphere distribution were found to differ significantly, especially at and below $50 \mathrm{~m}$ water depth. For instance, all major species showed relative maxima in coccoliths $\mathrm{L}^{-1}$ from November to January at $70 \mathrm{~m}$ water depth (Fig. 6). 

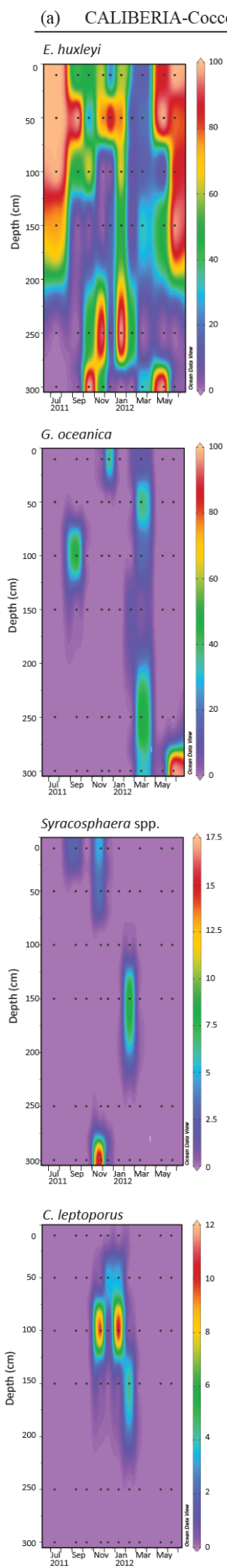

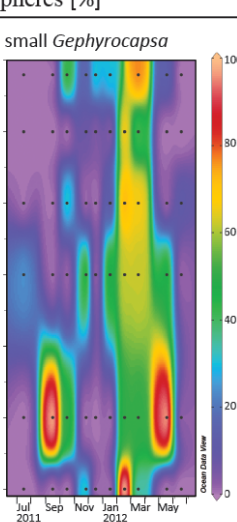

$$
\text { F. profunda }
$$
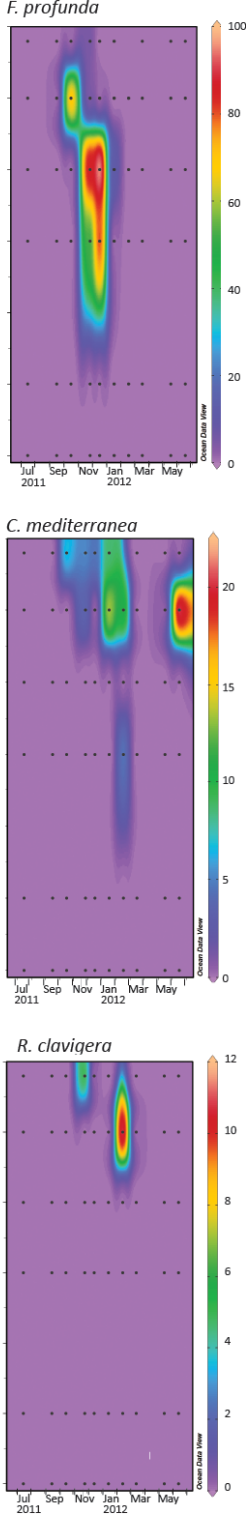

\section{(b) CALIBERIA-Coccoliths [\%]}
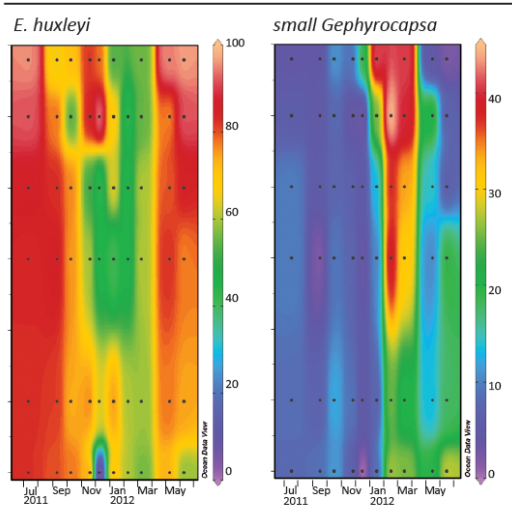

F. profunda
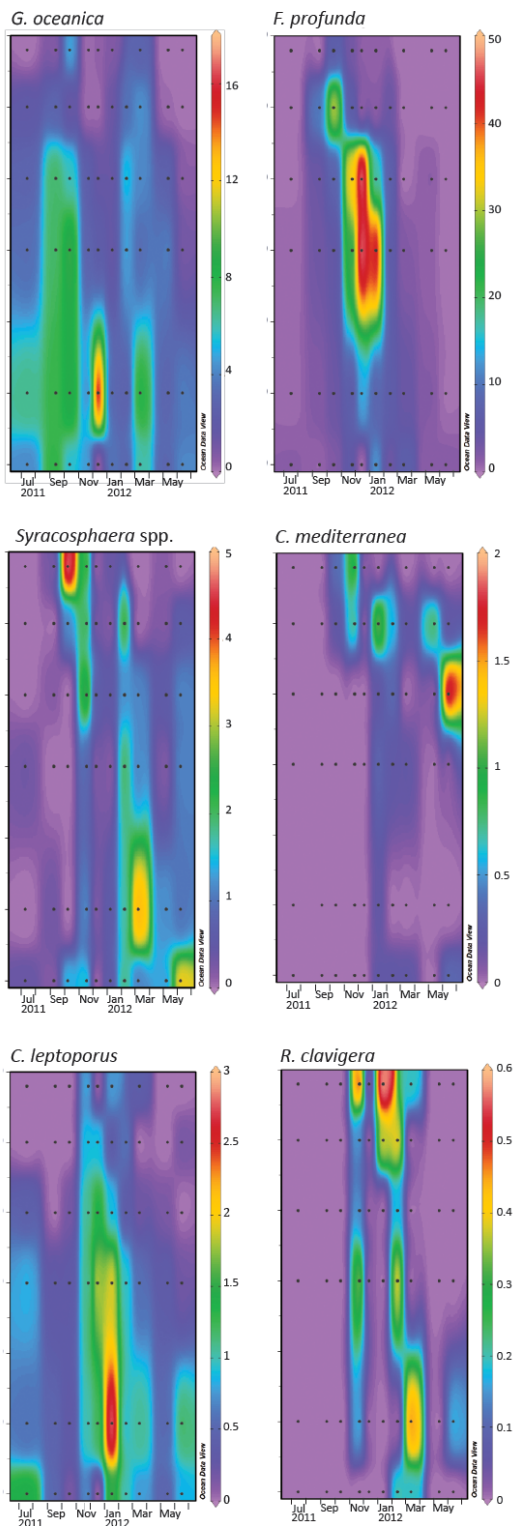

R. clavigera

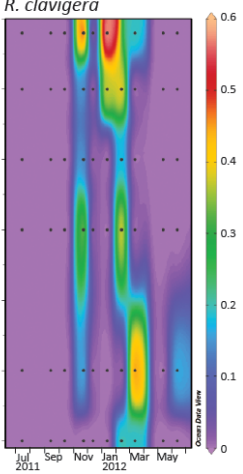

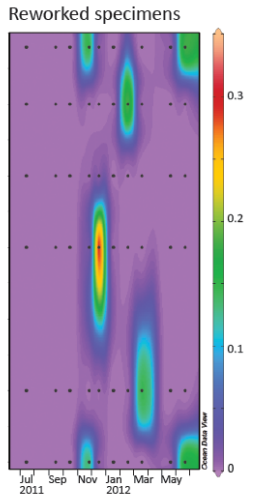

Figure 5. Relative abundance (\%) of major species of coccospheres (a) and coccoliths (b) in CALIBERIA station. Black dots represent the sampling month and depth. Note that each colour bar has been scaled to the maximum and minimum values of its corresponding species. 


\section{(a) RAIA-Coccospheres [Cells L $\left.{ }^{-1}\right]$}
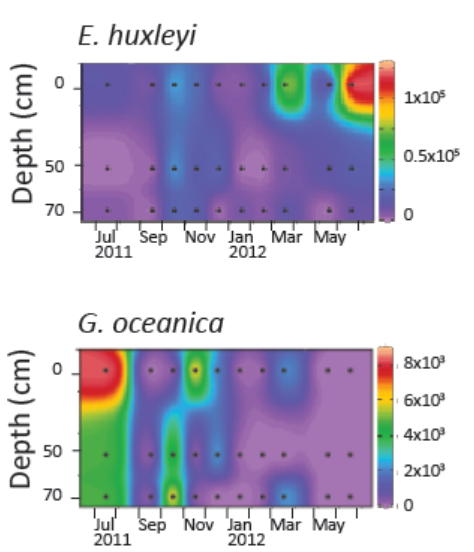

Syracosphaera spp.

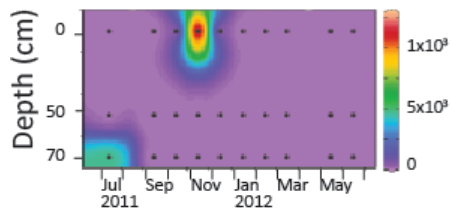

C. leptoporus

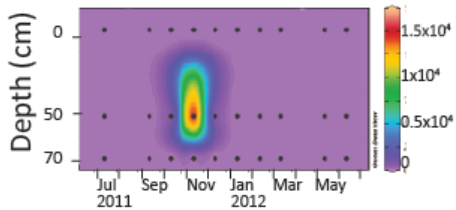

(b) RAIA-Coccoliths [Coccoliths $\left.\mathrm{L}^{-1}\right]$
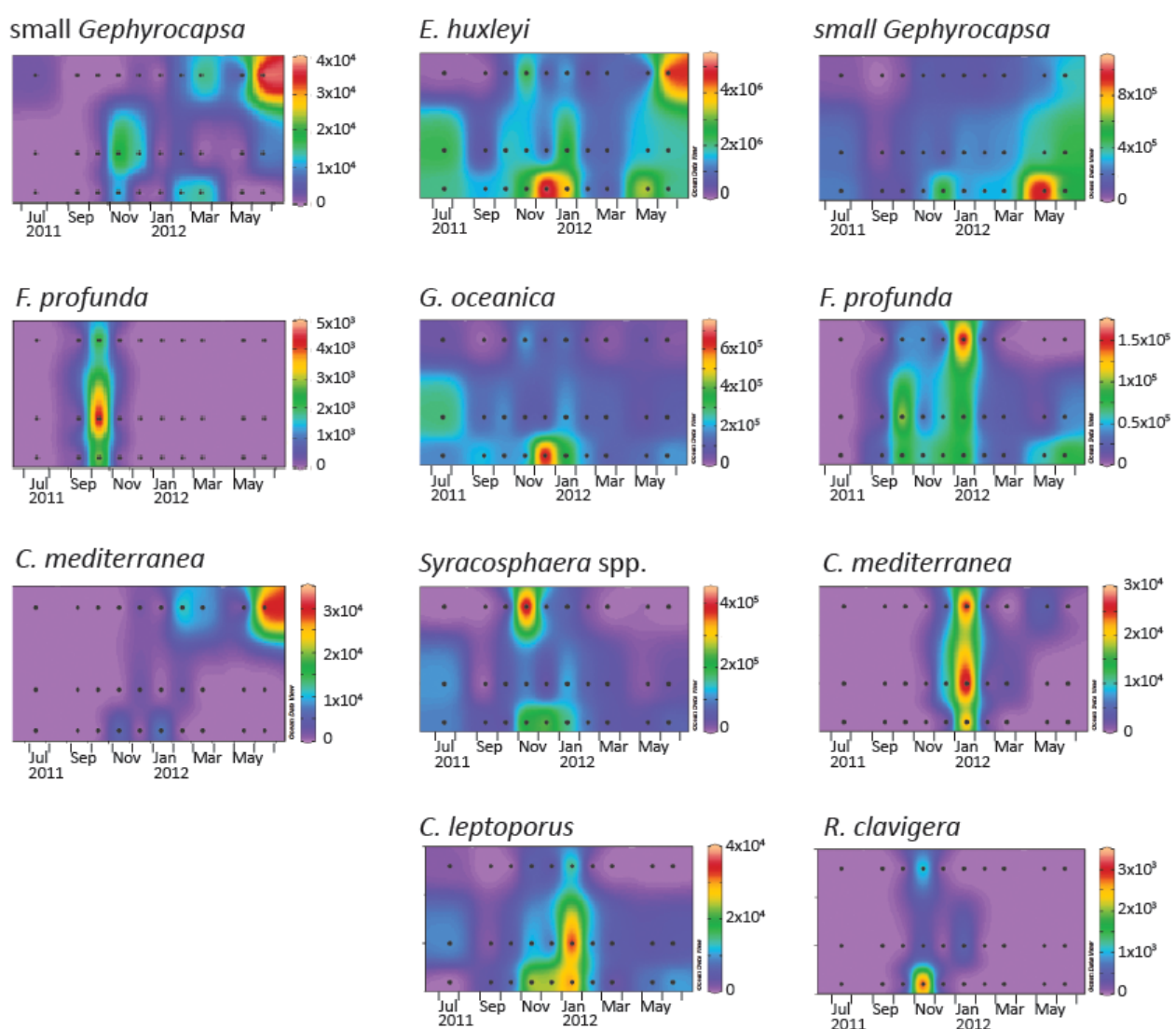

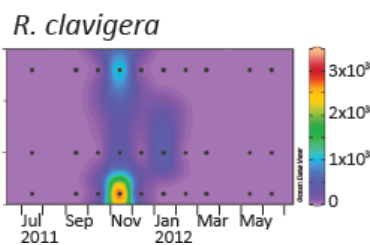

Figure 6. Absolute abundance of major species of coccospheres (a, given in cells $\mathrm{L}^{-1}$ ) and coccoliths (b, given in coccoliths $\mathrm{L}^{-1}$ ) in RAIA station. Black dots represent the sampling month and depth. Note that each colour bar has been scaled to the maximum and minimum values of its corresponding species.

\subsection{Outer-shelf temporal variability in species absolute abundance}

At the CALIBERIA outer-shelf station, E. huxleyi (up to $2 \times 10^{5}$ cells L $^{-1}$ ) was much more abundant during the upwelling regime (Fig. 7). The small Gephyrocapsa group (up to $1.75 \times 10^{5}$ cells L $^{-1}$ ) and $G$. oceanica (up to $1.4 \times 10^{5}$ cells L $^{-1}$ ) showed their highest abundance in March 2012, with the latter dominating at greater depths. $F$. profunda (up to $5 \times 10^{4}$ cells $\mathrm{L}^{-1}$ ) only appeared during winter, mostly between 50 and $100 \mathrm{~m}$ water depth, while Syracosphaera spp. abounded in September and, similarly to $R$. clavigera, November 2011 at $10 \mathrm{~m}$. C. mediterranea shows its highest density $\left(2 \times 10^{4}\right.$ cells L $\left.{ }^{-1}\right)$ in June 2012, and lower abundances during October-November 2011 within the first $50 \mathrm{~m}$. C. leptoporus appeared from November to January at and below $50 \mathrm{~m}$ water depth.

Except for G. oceanica and C. leptoporus, temporal distribution of coccolithophore species at the outer-shelf station were broadly mimicked by their corresponding coccoliths, although coccoliths showed a wider vertical dis- tribution (Fig. 7). Coccoliths of G. oceanica were much more abundant during the upwelling regime if compared with coccospheres of the same species. Coccoliths of Syracosphaera spp. coexisted with those of $C$. mediterranea and R. clavigera in November 2011 at $10 \mathrm{~m}$ water depth (Fig. 7). Coccoliths of $C$. leptoporus were present throughout the studied period at and below $100 \mathrm{~m}$ depth, and only appeared in the first $50 \mathrm{~m}$ during November-December.

\subsection{CCA}

The first canonical axis (CCA1) of the CCA CALIBERIA model explained $51 \%$ of the constrained inertia (i.e. variance) in the coccosphere data and was mostly related to the negative gradient of irradiance, and to the positive gradients of salinity and both Douro River and Minho River discharges (Fig. 8). The second canonical axis (CCA2) explained $22 \%$ of the constrained variance and showed a positive gradient with temperature and a negative relationship with $\mathrm{HPO}_{4}^{2-}$ and $\mathrm{NO}_{3}^{-}$. E. huxleyi was linked to the upwelling regime samples (June and July) and showed a positive relationship 
with temperature. The small Gephyrocapsa group was also related to the upwelling regime during March but, unlike $E$. huxleyi, linked to higher nutrient content. F. profunda was associated with the downwelling regime samples and presented a negative relationship with irradiance. G. oceanica was related to nutrients and mainly linked to samples below $50 \mathrm{~m}$ water depth. Syracosphaera spp., C. mediterranea, and $R$. clavigera are all associated with the poleward regime samples (November 2011-January 2012), positively related to temperature and negatively associated with nutrients. $C$. leptoporus, which is located next to the latter species, shows a positive relationship with salinity and temperature, and a negative one with nutrient content and irradiance.

\section{Discussion}

\subsection{General patterns in coccolithophore and coccolith abundance in the NW Iberian Margin}

This work represents the first year-long investigation of variability in coccolithophore abundance and distribution in the NW Iberian coastal upwelling system. On the one hand, maximum coccosphere abundance at both stations was comparable to maximum values reported for other northern, central, and southern locations along the Portuguese Margin and other major upwelling systems (Table 1). On the other hand, coccolith abundance in RAIA station was the same order of magnitude as that found by Ferreira and Cachão (2005) for an estuary in the SW Iberian Margin. Unfortunately, very few studies quantify the occurrence of free coccoliths in the water column, limiting comparison with other regions.

At both stations, the number of coccospheres drastically drops at below $50 \mathrm{~m}$ water depth, possibly due to rapid zooplankton grazing and coccolithophore disaggregation into coccoliths.

Total abundances of both coccospheres and coccoliths were higher at the outer-shelf station compared with the inner-shelf site (Figs. 3c, d), as previously stated by other studies based on water column and surface sediment samples recovered along longitudinal transects off the Portuguese coast (Abrantes and Moita, 1999; Cachão et al., 2000; Moita, 2001) and as inferred from Table 1. Higher cell densities agree with higher $\mathrm{Chl} a$ values and low diatom abundances further offshore in October 2011 and March 2012 (Figs. 2i and $3 \mathrm{a}, \mathrm{c}$ ). This suggests that under more (but not extreme) oligotrophic conditions this phytoplankton group can outcompete diatoms (Baumann et al., 2005; Gregg and Casey, 2007), and possibly be significant contributors to Chl $a$ values in the study area. In contrast, at the inner-shelf station where upwelling is more intense, the entrance of cold and nutrient rich waters favours diatoms proliferation at times of maximum Chl $a$, as recorded in July and September 2011. These results point to the need of considering coccol-

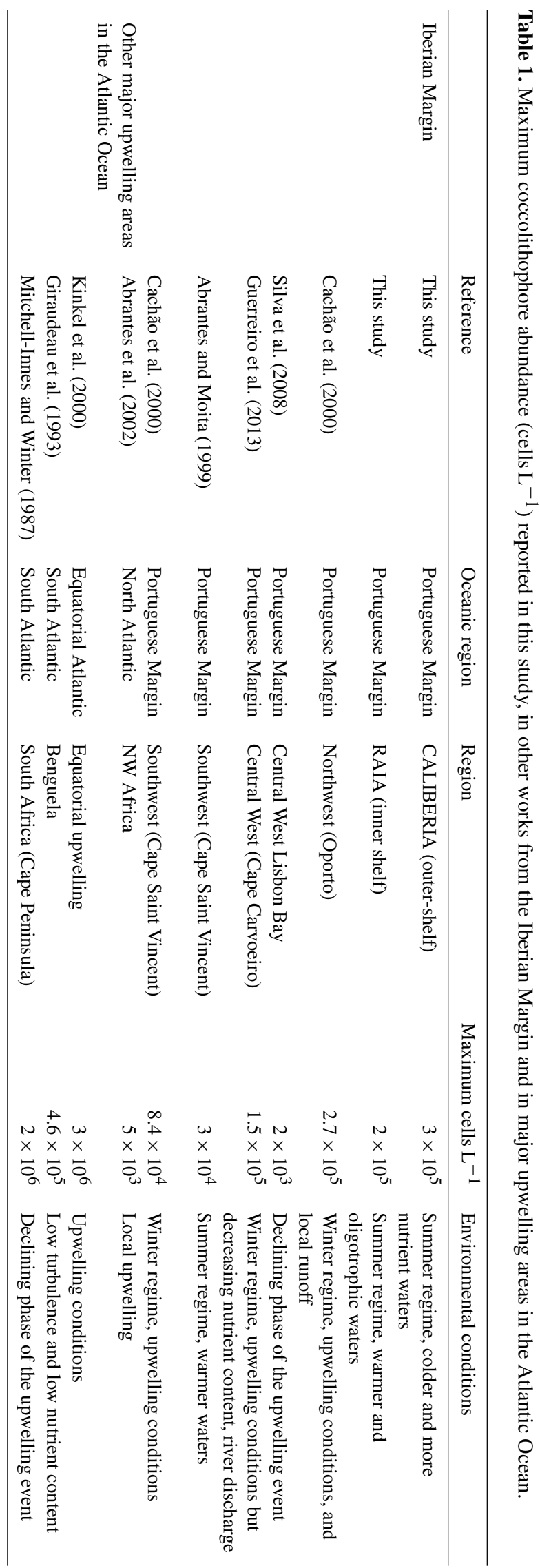

www.biogeosciences.net/15/245/2018/ 
(a) CALIBERIA-Coccospheres [Cells $\mathrm{L}^{-1}$ ]
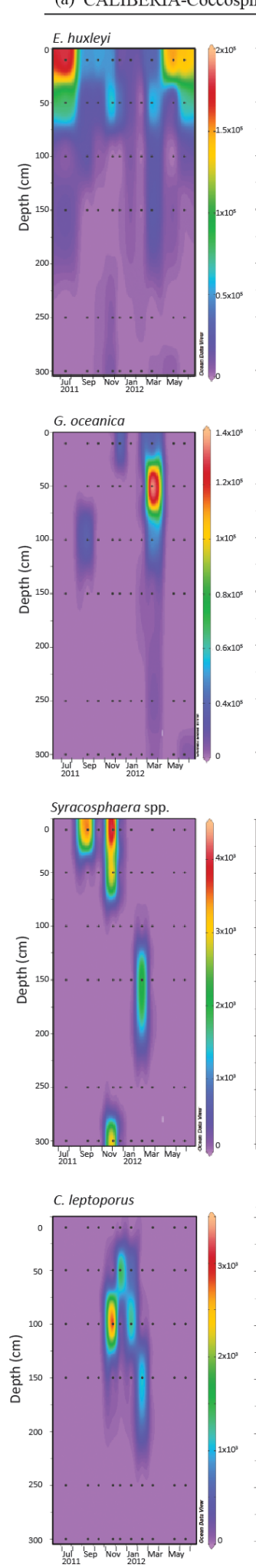

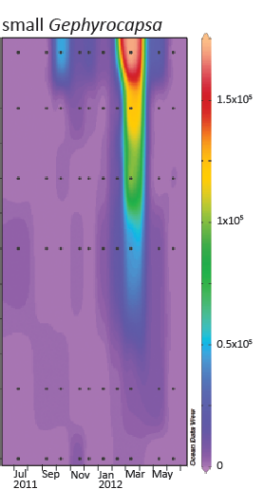

F. profunda

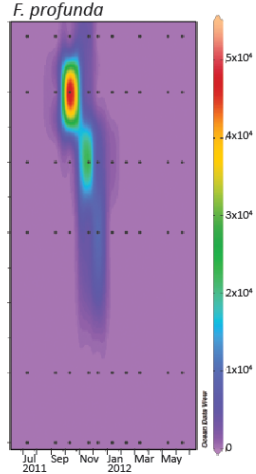

C. mediterranea

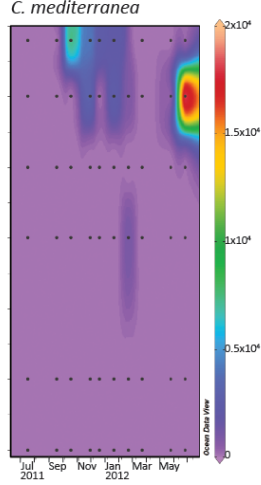

R. clavigera

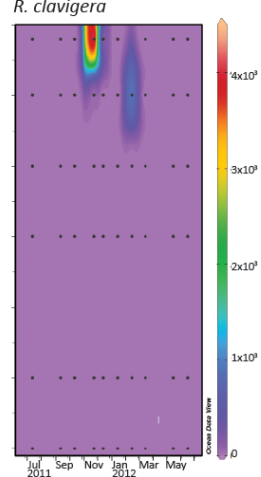

(b) CALIBERIA-Coccoliths [Coccoliths $\mathrm{L}^{-1}$ ]
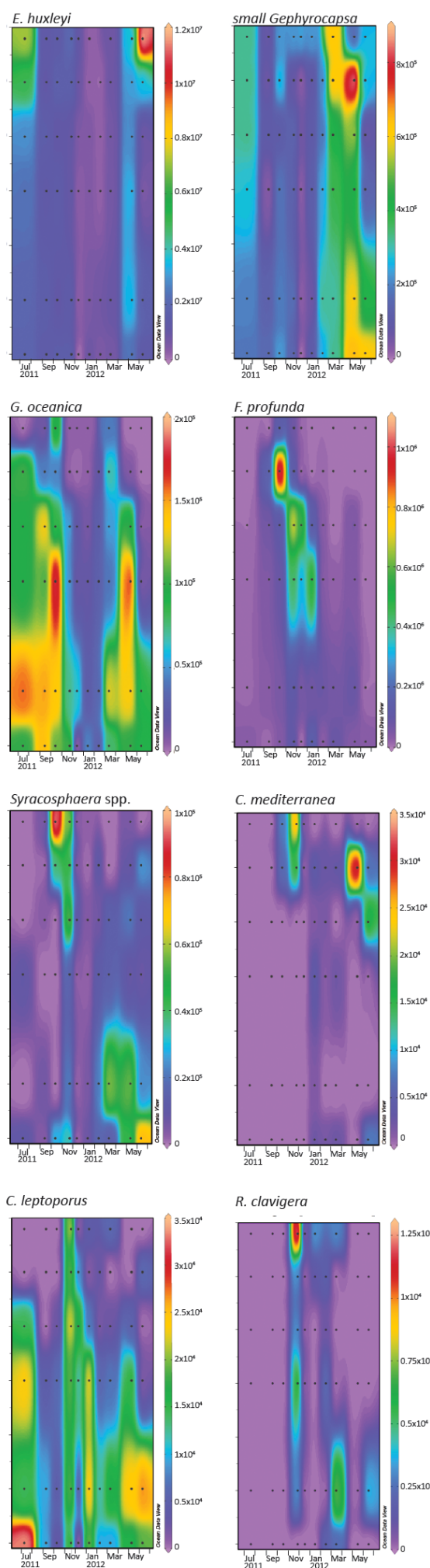

R. clavigera

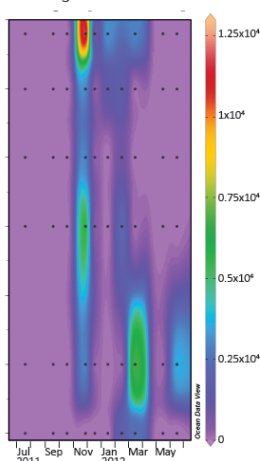

Figure 7. Absolute abundance of major species of coccospheres (a, given in cells $\mathrm{L}^{-1}$ ) and coccoliths (b, given in coccoliths $\left.\mathrm{L}^{-1}\right)$ in CALIBERIA station. Black dots represent the sampling month and depth. Note that each colour bar has been scaled to the maximum and minimum values of its corresponding species. 
ithophores to better explain primary productivity patterns at the NW Iberian continental margin.

\subsubsection{Inner-shelf temporal variability of coccosphere and coccolith abundance: the influence of coastal processes}

At the inner-shelf station, total coccosphere abundance presented maximum values during the upwelling season. By contrast, coccolith maxima were also observed during the downwelling regime, close to the seafloor $(75 \mathrm{~m})$. Given that environmental conditions at those times were unfavourable for coccolithophore growth and that no coccoliths nor coccospheres are observed above this depth to explain possible vertical settling, the existence of an allochthonous source of coccoliths (i.e. laterally transported from nearby locations) or resuspension of coccoliths from underlying sediments is proposed to explain these results. Further support for coccolith resuspension comes from the composition of the coccolith assemblage at those times (i.e. November-January and May), counting on many more taxa than the typical bloom-forming E. huxleyi and small Gephyrocapsa group (Fig. 6) recurrently dominating in productive conditions (Tyrrell and Merico, 2004). Simultaneously, large increases in wave height were observed (Fig. 2b), that is, high-energy wave-driven processes could have favoured resuspension of coccoliths from the underlying sediments. Our data are in agreement with Zúñiga et al. (2016), who studied downward $\mathrm{CaCO}_{3}$ fluxes at the same location and concluded that calcareous shelled organisms had to be remobilized from surface sediments during the highly hydrodynamic downwelling periods. As a consequence, discernment between autochthonous and allochthonous coccolithophore signals in the water column was not possible for these periods, preventing application of CCA to the RAIA data set. Guerreiro et al. (2013) have observed a rapid increase in coccolithophore production at the inner shelf of the central Iberian Margin influenced by a nutrient-rich buoyant plume resulting from intense river runoff. However, our results give no conclusive evidence as to whether freshwater lenses advected to RAIA station influenced the total coccosphere abundance (Figs. $2 \mathrm{f}$ and $3 \mathrm{~d}$ ).

\subsubsection{Outer-shelf temporal variability in coccosphere and coccolith abundance: the influence of seasonal dynamics}

At the outer-shelf site, coccosphere and coccolith abundances were seasonally modulated, showing higher values during the summer/upwelling regime and decreasing drastically in abundance during the winter/downwelling periods. Except for the coccosphere maximum in March 2012 at both stations, summer coccosphere and coccolith maxima were associated with high irradiance levels and relaxation of northerly winds during summer, conditions that promoted more stable water column and nutrient depletion (Figs. 2 and 3c). This affinity of coccolithophores for summer stratified conditions during the upwelling season was already observed by Silva et al. (2008) in Lisbon Bay, from a 4-year weekly-sampled data set. On the other hand, the coccosphere maximum in March 2012 occurred under completely different environmental conditions: cold and nutrient-rich waters characteristic of the onset of the upwelling season (Figs. 2 and 3c). Indeed, despite the general association of coccolithophores with weak upwelling and nutrient depletion, our results show that these phytoplankton groups may follow diverse life strategies, as demonstrated for this region by Guerreiro et al. (2013).

\subsection{Coccolithophore ecology and potential as paleoenvironmental indicators}

Both the coccosphere and coccolith major assemblages were mainly represented by E. huxleyi, the small Gephyrocapsa group, G. oceanica, F. profunda, Syracosphaera spp., C. mediterranea, and $C$. leptoporus at both stations. Given that resuspension events were found to mask the composition of the coccolith assemblage, and therefore to possibly influence the coccosphere assemblage, in the water column of RAIA station, discussion on coccolithophore ecology will be uniquely based on the coccosphere data set from CALIBERIA station.

E. huxleyi was the dominant species throughout the studied period regardless of the environmental conditions (Fig. 7). Higher cell densities of E. huxleyi, as well as the small Gephyrocapsa group, appeared highly related to the upwelling regime, in agreement with other studies carried out in the central Iberian Margin and other coastal upwelling regions (Ziveri et al., 1995; Baumann et al., 2008; Silva et al., 2008; Guerreiro et al., 2013; Narciso et al., 2016), where both taxa are proposed as indicators of productive periods. Despite this common affinity for the upwelling regime, temporal variability of their absolute abundance and the CCA (Figs. 7 and 8) also emphasize a connection of the small Gephyrocapsa group with spring samples, when colder and more nutrientrich ENACW waters upwelled on the shelf. In contrast, $E$. huxleyi was related to warmer and nutrient-poor waters during summer stratification when upwelling favourable winds relaxed (Zúñiga et al., 2017). Silva et al. (2008) also found both taxa were linked to the upwelling season, and noticed a preferential development of E. huxleyi during very weak upwelling events, although in spring and late summer. Yet, our outcomes highlight that both species are unambiguously linked to the upwelling regime.

G. oceanica was related to nutrient-rich waters below $50 \mathrm{~m}$, as evidenced by the CCA bi-plot (Figs. 7 and 8). This species is regarded as a component of the lower limit of the photic zone in coastal settings (Baumann and Boeckel, 2013), and has been related to relatively nutrient-rich coastal waters in the SW Iberian Margin (Ferreira and Cachão, 2005; Silva et al., 2008; Guerreiro et al., 2013; Guerreiro et al., 
2014). Its highest abundance coincides with maximum Chl $a$ values and higher nutrient content (Figs. $2 \mathrm{~g}-\mathrm{i}$ and 7), suggesting rapid response to nutrient availability (Guerreiro et al., 2013). This is supported by comparison of the temporal distribution of $G$. oceanica coccospheres and coccoliths. Water column conditions during the upwelling regime in July-November and May-June indicate ongoing relaxation of the upwelling event; at those times, only coccoliths of $G$. oceanica are present, indicating an ongoing or already terminated decay of the species population (Cachão and Oliveira, 2000). In contrast, in March, only coccospheres of G. oceanica are present, indicating new growth of cells of this species (Cachão and Oliveira, 2000).

F. profunda was related to the downwelling regime and deeper waters (Fig. 7 and 8), in agreement with its classical definition as a LPZ inhabitant (Okada and Honjo, 1973; Molfino and McIntyre, 1990). Since Molfino and McIntyre (1990) pointed out the inverse relationship of $F$. profunda with productivity in the upper photic zone (UPZ), its relative abundance in fossil records has been widely used to qualify and quantify past productivity variations in many oceanic regions (e.g. Beaufort, 1996; Beaufort et al., 1997, 2001; Grelaud et al., 2012), including the Atlantic Iberian Margin (Incarbona et al., 2010; Palumbo et al., 2013; Marino et al., 2014). Indeed, the ordination analysis for CALIBERIA supports this interpretation, relating $F$. profunda to deeper and downwelling regime samples (Fig. 8). Considering that the influence of Duero and Minho River discharges is limited to the first $10 \mathrm{~m}$ of the water column (Fig. 2f), the proximity of $F$. profunda to these environmental variables in the bi-plot is only interpreted as a consequence of their common temporal occurrence during the winter months. Contrary to expectation, coccolith abundance of $F$. profunda was not linked to deeper but to shallow waters at the inner-shelf station (Fig. 6). This fact supports coccolith remobilization from surface sediments at the inner continental shelf from October to January, preventing further interpretation of the coccolithophore ecology close to the coast during that period.

Syracosphaera spp. (mainly S. pulchra) is a major component during autumn (Fig. 7), in agreement with Beaufort and Heussner (2001). In spite of previous work (Guerreiro et al., 2015) suggesting that its imprint in the underlying sediments may be under-represented owing to selective dissolution of delicate coccoliths, several studies propose that this genus can dominate the water column assemblage in the study area in occasional periods - both close to the shore (Silva et al., 2008) and in open ocean conditions (Guerreiro et al., 2014). In this regard, S. pulchra along with Helicosphaera carteri, $C$. mediterranea, and $R$. clavigera constitute a minority but persistent late summer-autumn assemblage in the S and SW Iberian coast that has been proposed by previous authors (Cachão et al., 2000; Silva et al., 2008, 2009; Moita et al., 2010) as a tracer for ENACW of subtropical origin (Fiúza, 1983). Apart from H. carteri, this assemblage was observed

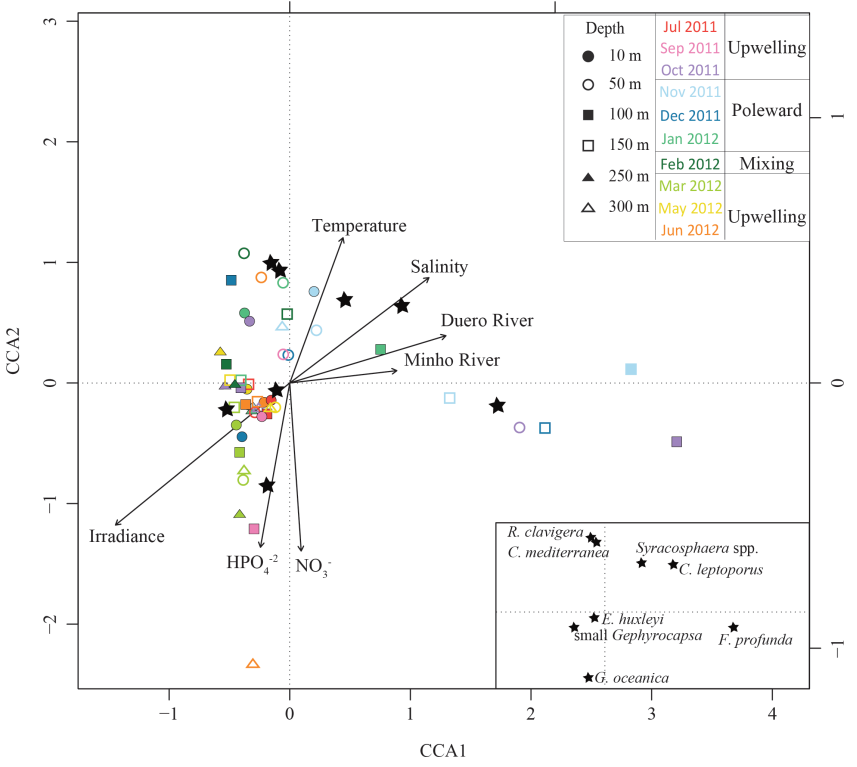

Figure 8. Ordination graph for the first two axes of the CCA for CALIBERIA data sets. The species scores are represented by stars and environmental variables by arrows. Samples are shown through coloured symbols according to their sampling month and depth.

further offshore in November 2011 (Fig. 7), when the upper water column was characterized by warmer, saltier, and nutrient-poor waters if compared to the inner-shelf station (Fig. 2), and as emphasized by the CCA (Fig. 8). A similar assemblage including these three species has been observed in the Central North Atlantic Ocean and was related to warm and oligotrophic waters (Narciso et al., 2016). Although further research is required to assess its preservation in the fossil record, our results broaden the geographical extent of this assemblage as a potential proxy for ENACW of subtropical origin conveyed northward by the IPC.

This assemblage coexists with C. leptoporus, which is also present in the following winter months at and below $50 \mathrm{~m}$ water depth (Fig. 7). In a study of the vertical distribution of extant coccolithophores, Baumann et al. (2008) describe C. leptoporus as a deep-dwelling species, along with F. profunda. This species has shown broad tolerance to environmental conditions and has been related to warm and oligotrophic waters (Giraudeau, 1992; Silva et al., 2013) as well as to colder, fresher, and eutrophic waters (Baumann et al., 2016), in this and other regions. In this study, CCA points to a clear relationship of $C$. leptoporus with saltier, warmer, and poor-nutrient waters, and low levels of irradiance (Fig. 8). These results are in good agreement with previous works in the study area (Silva et al., 2008, 2009; Guerreiro et al., 2014), where C. leptoporus is regarded as a tracer of nutrientdepleted water masses of subtropical origin in the study area, suggesting a strong regional hydrographic control on its distribution. 


\section{Conclusions}

This paper reports on the assessment of the temporal and spatial variability and distribution of coccolithophore and coccolith abundances in the NW Iberian coastal upwelling system. Our results highlight the role of calcareous nanoplankton as primary producers in the study area and suggest that this group might be a potential contributor to higher Chl $a$ values at the outer Iberian Margin continental shelf. A coastal-offshore gradient was observed in coccosphere abundance, contrary to that of diatoms, with an increase in both coccosphere and coccolith abundances towards the outer shelf where the water column was characterized by relatively more oligotrophic conditions. Even so, temporal variability in coccosphere and coccolith abundances differs between stations. At the inner shelf, coastal processes like strong stormy events were found to resuspend coccoliths from the underlying sediments, masking the autochthonous coccolith assemblage in the water column and hampering interpretation of their ecology. Further offshore, the variability in coccosphere and coccolith abundance is modulated by the seasonal upwelling-downwelling regime. Higher abundances of both forms were observed during spring-summer, when high irradiance levels and upwelling favourable winds promote optimal conditions for coccolithophore growth. We found that higher coccosphere and coccolith abundance occurred mostly under more stratified and nutrient-poor conditions, but also when the cold and nutrient-rich ENACW upwelled onto the continental shelf.

This information on coccolithophore distribution and temporal variability might be of great use to qualitatively interpret coccolith fossil records in terms of past dynamics of the upper water column and thus to monitor large-scale modes of surface oceanic circulation along the NW Iberian Margin, but more specifically in locations far from the influence of coastal hydrodynamic processes. Increases in the absolute abundance of both E. huxleyi and the small Gephyrocapsa group in the fossil record are proposed as indicators of upwelling periods and therefore persistent northerly winds. Despite their common affinity for the upwelling regime, distinct ecological preferences were found between both taxa and attributed to their affinity for different stages of the upwelling event: E. huxleyi was linked to upwelling relaxation conditions (i.e. more stable, warmer and nutrient-poor water column) while the small Gephyrocapsa group was associated with early stages of the upwelling event (i.e. colder waters and higher nutrient availability), similarly to G. oceanica. Conversely, $F$. profunda is proposed as a proxy for the downwelling regime and low-productivity conditions. The assemblage composed of S. pulchra, C. mediterranea, and R. clavigera may be used as a tracer of the hydrographic influence of the IPC, which carries warmer and nutrient-poor southerly waters. More broadly, C. leptoporus is proposed as an indicator of warmer, saltier, and oligotrophic waters during the downwelling/winter regime.
Data availability. The coccolithophore data set is available from the corresponding author upon request. The environmental data set is part of ongoing research and will be equally accessible after the aforementioned investigation is completed. 


\section{Appendix A}

Table A1. Taxonomic list of the identified species. Their presence at each station is denoted by $\times$.

\begin{tabular}{|c|c|c|}
\hline Taxon & CALIBERIA & RAIA \\
\hline Braarudosphaera bigelowii (Gran and Braarud, 1935) & $x$ & $x$ \\
\hline Coronosphaera mediterranea (Lohmann, 1902) & $x$ & $\times$ \\
\hline Calcidiscus leptoporus (Murray and Blackman, 1898) & $x$ & $\times$ \\
\hline Coccolithus pelagicus ssp. braarudii (Gaarder, 1962) & $x$ & $x$ \\
\hline Coccolithus pelagicus (Wallich, 1877) Schiller, 1930 ssp. pelagicus & $x$ & $x$ \\
\hline Discosphaera tubifera (Murray and Blackman, 1898) & $x$ & \\
\hline Emiliania huxleyi (Lohmann, 1902) & $x$ & $\times$ \\
\hline Florisphaera profunda (Okada and Honjo, 1973) & $x$ & $x$ \\
\hline Gephyrocapsa aperta Kamptner, 1963 & $x$ & $x$ \\
\hline Gephyrocapsa ericsonii McIntyre and Bé, 1967 & $x$ & $\times$ \\
\hline Gephyrocapsa muellerae Bréhéret, 1978 & $x$ & $\times$ \\
\hline Gephyrocapsa oceanica Kamptner, 1943 & $x$ & $x$ \\
\hline Gladiolithus flabellatus (Halldal \& Markali, 1955) & $x$ & \\
\hline Helicosphaera spp. (mainly H. carteri (Wallich, 1877)) & $x$ & $\times$ \\
\hline Oolithotus fragilis (Lohmann, 1912) & $x$ & $x$ \\
\hline Pontosphaera spp. Schiller, 1925 & $x$ & $x$ \\
\hline Rhabdospahera clavigera Murray and Blackman, 1898 & $x$ & $\times$ \\
\hline Scyphosphaera apsteinii Lohmann, 1902 & $x$ & $\times$ \\
\hline Syracosphaera spp. (mainly S. pulchra, Lohmann, 1902) & $x$ & $\times$ \\
\hline Umbellosphaera spp. (mainly U. tenuis (Kamptner, 1937)) & $x$ & $x$ \\
\hline Umbilicosphaera sibogae (Weber-van Bosse, 1901) & $x$ & $x$ \\
\hline
\end{tabular}


Competing interests. The authors declare that they have no conflict of interest.

Acknowledgements. The authors would like to thank Mario Cachão, Maria Triantaphyllou, and two other anonymous reviewers for their valuable comments and suggestions to improve the quality of the paper. The authors want to thank the captain and crew of the RV Mytilus (CSIC). This work was funded by the EXCAPA project (10MDS402013PR) funded by Xunta de Galicia, and the CALIBERIA project supported the coccolithophore analysis (PTDC/MAR/102045/2008 from Fundação para a Ciência e a Tecnologia - Portugal - and COMPETE/FEDERFCOMP-01-0124-FEDER-010599). Project CGL2015-68459-P from Ministerio de Economía y Competitividad also contributed to the funding of this study. B. A. was supported by a FPU grant (AP2010-2559) of the Ministry of Education of Spain and by an ETH Zurich Postdoctoral Fellowship from the Swiss Federal Institute of Technology in Zurich (ETHZ). D. Z. was funded by a postdoctoral fellowship (Plan I2C) from Xunta de Galicia (Spain). F. G. was funded by RAIA.co (0520_RAIA.co_1_E). N. V.-R. was funded by Isabel Barreto Program (Xunta de Galicia, Spain). M. F. (BI/PTDC/MAR/102045/2008/2010016), C. S. (BI/PTDC/MAR/102045/2008/2010-022) and C. C. (BI/PTDC/MAR/102045/2008/2011-027) were supported by CALIBERIA project. E. S. was funded by a postdoctoral fellowship (SFRH/BPD/111433/2015) from FCT and from Plurianual/Estratégico project (UID/Multi/04326/2013).

Edited by: Clare Woulds

Reviewed by: Mário Cachão and four anonymous referees

\section{References}

Abrantes, F. and Moita, M. T.: Water column and recent sediment data on diatoms and coccolithophorids, off Portugal, confirm sediment record of upwelling events, Oceanol. Acta, 22, 319336, 1999.

Abrantes, F., Meggers, H., Nave, S., Bollman, J., Palma, S., Sprengel, C., Henderiks, J., Spies, A., Salgueiro, E., Moita, T., and Neuer., S.: Fluxes of micro-organisms along a productivity gradient in the Canary Islands region $\left(29^{\circ} \mathrm{N}\right)$ : Implications for paleoreconstructions, Deep-Sea Res. Pt. II, 49, 3599-3629, 2002.

Alvarez, I., Gomez-Gesteira, M., deCastro, M., Lorenzo, M. N., Crespo, A. J. C., and Dias, J. M.: Comparative analysis of upwelling influence between the western and northern coast of the Iberian Peninsula, Cont. Shelf Res., 31, 388-399, 2011.

Álvarez-Salgado, X. A., Figueiras, F. G., Pérez, F. F., Groom, S., Nogueira, E., Borges, A. V., Chou, L., Castro, C. G., Moncoiffé, G., Ríos, A. F., Miller, A. E. J., Frankignoulle, M., Savidge, G., and Wollast, R.: The Portugal coastal counter current off NW Spain: new insights on its biogeochemical variability, Prog. Oceanogr., 56, 281-321, 2003.

Amore, F. O., Flores, J. A., Voelker, A. H. L., Lebreiro, S. M., Palumbo, E., and Sierro, F. J.: A Middle Pleistocene Northeast Atlantic coccolithophore record: Paleoclimatology and paleoproductivity aspects, Mar. Micropaleontol., 90-91, 44-59, 2012.
Arístegui, J., Barton, E. D., Álvarez-Salgado, X. A., Santos, A. M. P., Figueiras, F. G., Kifani, S., Hernández-León, S., Mason, E., Machú, E., and Demarcq, H.: Sub-regional ecosystem variability in the Canary Current upwelling, Prog. Oceanogr., 83, 33-48, 2009.

Baumann, K.-H. and Boeckel, B.: Spatial distribution of living coccolithophores in the southwestern Gulf of Mexico, J. Micropalaeontol., 32, 123-133, 2013.

Baumann, K. H., Andruleit, H., Boeckel, B., Geisen, M., and Kinkel, H.: The significance of extant coccolithophores as indicators of ocean water masses, surface water temperature, and palaeoproductivity: a review, Palaeont. Z., 79, 93-112, 2005.

Baumann, K. H., Boeckel, B., and Čepek, M.: Spatial distribution of living coccolithophores on an East-West transect in the subtropical South Atlantic, Journal of Nannoplankton Research 30, 9-21, 2008.

Baumann, K.-H., Saavedra-Pellitero, M., Böckel, B., and Ott, C.: Morphometry, biogeography and ecology of Calcidiscus and Umbilicosphaera in the South Atlantic, Revue de Micropaléontologie, 59, 239-251, 2016.

Beaufort, L.: Dynamics of the monsoon in the equatorial Indian Ocean over the last 260,000 years, Quatern. Int., 31, 13-18, 1996.

Beaufort, L. and Heussner, S.: Seasonal dynamics of calcareous nannoplankton on a West European continental margin: the Bay of Biscay, Mar. Micropaleontol., 43, 27-55, 2001.

Beaufort, L., Lancelot, Y., Camberlin, P., Cayre, O., Vincent, E., Bassinot, F., and Labeyrie, L.: Insolation Cycles as a Major Control of Equatorial Indian Ocean Primary Production, Science, 278, 1451-1454, 1997.

Beaufort, L., de Garidel-Thoron, T., Mix, A. C., and Pisias, N. G.: ENSO-like Forcing on Oceanic Primary Production During the Late Pleistocene, Science, 293, 2440-2444, 2001.

Cachão, M. and Moita, M. T.: Coccolithus pelagicus, a productivity proxy related to moderate fronts off Western Iberia, Mar. Micropaleontol., 39, 131-155, 2000.

Cachão, M. and Oliveira, A.: (Cocco)liths versus (cocco)spheres: approaching the ecological performance of coccolithophores, Journal of Nannoplankton Research, 22, 29-34, 2000.

Cachão, M., Oliveira, A., and Vitorino, J.: Subtropical winter guests, offshore Portugal, Journal of Nannoplankton Research, 22, 19-26, 2000.

Castro, C. G., Álvarez-Salgado, X. A., Figueiras, F. G., Pérez, F. F., and Fraga, F.: Transient hydrographic and chemical conditions affecting microplankton populations in the coastal transitions zone of the Iberian upwelling system (NW Spain) in September 1986, J. Mar. Res., 55, 321-352, 1997.

Dias, J. M. A., Gonzalez, R., Garcia, C., and Diaz-del-Rio, V.: Sediment distribution patterns on the Galicia-Minho continental shelf, Prog. Oceanogr., 52, 215-231, 2002a.

Dias, J. M. A., Jouanneau, J. M., Gonzalez, R., Araújo, M. F., Drago, T., Garcia, C., Oliveira, A., Rodrigues, A., Vitorino, J., and Weber, O.: Present day sedimentary processes on the northern Iberian shelf, Prog. Oceanogr., 52, 249-259, 2002 b.

Fatela, F. and Taborda, R.: Confidence limits of species proportions in microfossil assemblages, Mar. Micropaleontol., 45, 169-174, 2002.

Ferreira, J. and Cachão, M.: Calcareous nannoplankton from the Guadiana estuary and Algarve continental shelf (southern Portugal), Thalassas, 21, 35-44, 2005. 
Ferreira, J., Cachao, M., and González, R.: Reworked calcareous nannofossils as ocean dynamic tracers: The Guadiana shelf case study (SW Iberia), Estuar. Coast. Shelf S., 79, 59-70, 2008.

Figueiras, F. G., Labarta, U., and Fernández Reiriz, M. J.: Coastal upwelling, primary production and mussel growth in the Rías Baixas of Galicia, Hydrobiologia, 484, 121-131, 2002.

Fiúza, A. F. G.: Upwelling Patterns off Portugal, in: Coastal Upwelling Its Sediment Record: Part A: Responses of the Sedimentary Regime to Present Coastal Upwelling, edited by: Suess, E. and Thiede, J., Springer US, Boston, MA, 85-98, 1983.

Flores, J. A. and Marino, M.: Pleistocene calcareous nannofossil stratigraphy for ODP Leg 177 (Atlantic sector of the Southern Ocean), Mar. Micropaleontol., 45, 191-224, 2002.

Flores, J. A., Gersonde, R., and Sierro, F. J.: Pleistocene fluctuations in the Agulhas Current Retroflection based on the calcareous plankton record, Mar. Micropaleontol., 37, 1-22, 1999.

Flores, J. A., Colmenero-Hidalgo, E., Mejía-Molina, A. E., Baumann, K.-H., Henderiks, J., Larsson, K., Prabhu, C. N., Sierro, F. J., and Rodrigues, T.: Distribution of large Emiliania huxleyi in the Central and Northeast Atlantic as a tracer of surface ocean dynamics during the last 25,000 years, Mar. Micropaleontol., 76, 53-66, 2010.

Fraga, F.: Upwelling off the Galician Coast, Northwest Spain, in: Coastal Upwelling American Geophysical Union, 176-182, 1981.

Giraudeau, J.: Distribution of Recent nannofossils beneath the Benguela system: Southwest African continental margin, Mar. Geol., 108, 219-237, 1992.

Giraudeau, J., Monteiro, P. M. S., and Nikodemus, K.: Distribution and malformation of living coccolithophores in the northern Benguela upwelling system off Namibia, Mar. Micropaleontol., 22, 93-110, 1993.

Gregg, W. W. and Casey, N. W.: Modeling coccolithophores in the global oceans, Deep-Sea Res. Pt. II, 54, 447-477, 2007.

Grelaud, M., Marino, G., Ziveri, P., and Rohling, E. J. C. P. A.: Abrupt shoaling of the nutricline in response to massive freshwater flooding at the onset of the last interglacial sapropel event, Paleoceanography, 27, PA3208, https://doi.org/10.1029/2012PA002288, 2012.

Guerreiro, C., Oliveira, A., de Stigter, H., Cachão, M., Sá, C., Borges, C., Cros, L., Santos, A., Fortuño, J.-M., and Rodrigues, A.: Late winter coccolithophore bloom off central Portugal in response to river discharge and upwelling, Cont. Shelf Res., 59, 65-83, 2013.

Guerreiro, C., Sá, C., de Stigter, H., Oliveira, A., Cachão, M., Cros, L., Borges, C., Quaresma, L., Santos, A. I., Fortuño, J.M., and Rodrigues, A.: Influence of the Nazaré Canyon, central Portuguese margin, on late winter coccolithophore assemblages, Deep-Sea Res. Pt. II, 104, 335-358, 2014.

Guerreiro, C., de Stigter, H., Cachão, M., Oliveira, A., and Rodrigues, A.: Coccoliths from recent sediments of the central Portuguese margin: Taphonomical and ecological inferences, Mar. Micropaleontol., 114, 55-68, 2015.

Hansen, H. P. and Grassoff, K.: Automated Chemical Analysis, Methods of Seawater Analysis, Verlag Chemie, Weinheim, 1983.

Haynes, R. and Barton, E. D.: A poleward flow along the Atlantic coast of the Iberian peninsula, J. Geophys. Res.-Oceans, 95, 11425-11441, 1990.
Incarbona, A., Martrat, B., Di Stefano, E., Grimalt, J. O., Pelosi, N., Patti, B., and Tranchida, G.: Primary productivity variability on the Atlantic Iberian Margin over the last 70,000 years: Evidence from coccolithophores and fossil organic compounds, Paleoceanography, 25, PA2218, https://doi.org/10.1029/2008PA001709, 2010.

Kinkel, H., Baumann, K. H., and C̆epek, M.: Coccolithophores in the equatorial Atlantic Ocean: response to seasonal and Late Quaternary surface water variability, Mar. Micropaleontol., 39, 87-112, 2000 .

Marino, M., Maiorano, P., Tarantino, F., Voelker, A., Capotondi, L., Girone, A., Lirer, F., Flores, J.-A., and Naafs, B. D. A.: Coccolithophores as proxy of seawater changes at orbital-to-millennial scale during middle Pleistocene Marine Isotope Stages 14-9 in North Atlantic core MD01-2446, Paleoceanography, 29, 518532, 2014.

McIntyre, A.: Coccoliths as Paleoclimatic Indicators of Pleistocene Glaciation, Science, 158, 1314-1317, 1967.

McIntyre, A. and Bé, A. W. H.: Modern coccolithophoridae of the Atlantic Ocean. Placoliths and cyrtoliths, Deep Sea Research and Oceanographic Abstracts, 14, 561-597, 1967.

Mitchell-Innes, B. A. and Winter, A.: Coccolithophores: a major phytoplankton component in mature upwelled waters off the Cape Peninsula, South Africa in March, 1983, Mar. Biol., 95, 25-30, 1987.

Moita, M. T.: Estrutura, variabilidade e dinâmica do Fitoplâncton na Costa de Portugal Continental, PhD Thesis, Faculdade de Ciencias da Universidade de Lisboa, Lisbon, Portugal, 272, 2001.

Moita, M. T., Silva, A., Palma, S., and Vilarinho, M. G.: The coccolithophore summer-autumn assemblage in the upwelling waters of Portugal: Patterns of mesoscale distribution (1985-2005), Estuar. Coast. Shelf S., 87, 411-419, 2010.

Molfino, B. and McIntyre, A.: Precessional forcing of nutricline dynamics in the equatorial Atlantic, Science, 249, 766-769, 1990.

Narciso, Á., Gallo, F., Valente, A., Cachão, M., Cros, L., Azevedo, E. B., and e Ramos, J. B.: Seasonal and interannual variations in coccolithophore abundance off Terceira Island, Azores (Central North Atlantic), Cont. Shelf Res., 117, 43-56, 2016.

Oberle, F. K. J., Storlazzi, C. D., and Hanebuth, T. J. J.: Wavedriven sediment mobilization on a storm-controlled continental shelf (Northwest Iberia), J. Marine Syst., 139, 362-372, 2014.

Okada, H. and Honjo, S.: The distribution of oceanic coccolithophorids in the Pacific, Deep Sea Research and Oceanographic Abstracts, 20, 355-374, 1973.

Oksanen, J., Blanchet, F. G., Friendly, M., Kindt, R., Legendre, P., McGlinn, D., Minchin, P. R., O’Hara, R. B., Simpson, G. L., Solymos, P., Stevens, M. H. H., Szoecs, E., and Wagner, H.: vegan: Community Ecology Package, R package version 2.4-0, https://CRAN.R-project.org/package=vegan (last access: 5 August 2017), 2016.

Palumbo, E., Flores, J. A., Perugia, C., Emanuele, D., Petrillo, Z., Rodrigues, T., Voelker, A. H. L., and Amore, F. O.: Abrupt variability of the last $24 \mathrm{ka}$ BP recorded by coccolithophore assemblages off the Iberian Margin (core MD03-2699), J. Quaternary Sci., 28, 320-328, 2013.

Parente, A., Cachão, M., Baumann, K.-H., de Abreu, L., and Ferreira, J.: Morphometry of Coccolithus pelagicus s: 1. (Coccolithophore, Haptophyta) from offshore Portugal, during the last 200 kyr, Micropaleontology, 50, 107-120, 2004. 
Peliz, Á., Dubert, J., Santos, A. M. P., Oliveira, P. B., and Le Cann, B.: Winter upper ocean circulation in the Western Iberian BasinFronts, Eddies and Poleward Flows: an overview, Deep-Sea Res. Pt. I, 52, 621-646, 2005.

R Core Team: R: A language and environment for statistical computing. R Foundation for Statistical Computing, Viena, Austria, available at: http://www.R-project.org (last access: 15 August 2016), 2015.

Relvas, P., Barton, E. D., Dubert, J., Oliveira, P. B., Peliz, Á., da Silva, J. C. B., and Santos, A. M. P.: Physical oceanography of the western Iberia ecosystem: Latest views and challenges, Prog. Oceanogr., 74, 149-173, 2007.

Sánchez-Goñi, M. F., Eynaud, F., Turon, J. L., and Shackleton, N. J.: High resolution palynological record off the Iberian margin: direct land-sea correlation for the Last Interglacial complex, Earth Planet. Sc. Lett., 171, 123-137, 1999.

Sánchez-Goñi, M., Cacho, I., Turon, J., Guiot, J., Sierro, F. J., Peypouquet, J., Grimalt, J., and Shackleton, N.: Synchroneity between marine and terrestrial responses to millennial scale climatic variability during the last glacial period in the Mediterranean region, Clim. Dynam., 19, 95-105, 2002.

Silva, A., Palma, S., and Moita, M. T.: Coccolithophores in the upwelling waters of Portugal: Four years of weekly distribution in Lisbon bay, Cont. Shelf Res., 28, 2601-2613, 2008.

Silva, A., Palma, S., Oliveira, P. B., and Moita, M. T.: Composition and interannual variability of phytoplankton in a coastal upwelling region (Lisbon Bay, Portugal), J. Sea Res., 62, 238-249, 2009.

Silva, A., Brotas, V., Valente, A., Sá, C., Diniz, T., Patarra, R. F., Álvaro, N. V., and Neto, A. I.: Coccolithophore species as indicators of surface oceanographic conditions in the vicinity of Azores islands, Estuar. Coast. Shelf S., 118, 50-59, 2013.

Stoll, H. M., Rosenthal, Y., and Falkowski, P.: Climate proxies from $\mathrm{Sr} / \mathrm{Ca}$ of coccolith calcite: calibrations from continuous culture of Emiliania huxleyi, Geochim. Cosmochim. Ac., 66, 927-936, 2002 .
Tenore, K. R., Alonso-Noval, M., Alvarez-Ossorio, M., Atkinson, L. P., Cabanas, J. M., Cal, R. M., Campos, H. J., Castillejo, F., Chesney, E. J., Gonzalez, N., Hanson, R. B., McClain, C. R., Miranda, A., Roman, M. R., Sanchez, J., Santiago, G., Valdes, L., Varela, M., and Yoder, J.: Fisheries and oceanography off Galicia, NW Spain: Mesoscale spatial and temporal changes in physical processes and resultant patterns of biological productivity, J. Geophys. Res.-Oceans, 100, 10943-10966, 1995.

Tyrrell, T. and Merico, A.: Emiliania huxleyi: bloom observations and the conditions that induce them, in: Coccolithophores: From Molecular Processes to Global Impact, edited by: Thierstein, $\mathrm{H}$. R. and Young, J. R., Springer, Berlin Heidelberg, Berlin, Heidelberg, 75-97, 2004.

Vitorino, J., Oliveira, A., Jouanneau, J. M., and Drago, T.: Winter dynamics on the northern Portuguese shelf. Part 2: bottom boundary layers and sediment dispersal, Prog. Oceanogr., 52, 155-170, 2002.

Young, J. R., Geisen, M., Cros, L., Kleijne, A., Sprengel, C., Probert, I., and Østergaard, J.: A guide to extant coccolithophore taxonomy, Journal of Nannoplankton Research, 1, 1-125, 2003.

Ziveri, P., Thunell, R. C., and Rio, D.: Seasonal changes in coccolithophore densities in the Southern California Bight during 1991-1992, Deep-Sea Res. Pt. I, 42, 1881-1903, 1995.

Zúñiga, D., Villacieros-Robineau, N., Salgueiro, E., Alonso-Pérez, F., Rosón, G., Abrantes, F., and Castro, C. G.: Particle fluxes in the NW Iberian coastal upwelling system: Hydrodynamical and biological control, Cont. Shelf Res., 123, 89-98, 2016.

Zúñiga, D., Santos, C., Froján, M., Salgueiro, E., Rufino, M. M., De la Granda, F., Figueiras, F. G., Castro, C. G., and Abrantes, F.: Diatoms as a paleoproductivity proxy in the NW Iberian coastal upwelling system (NE Atlantic), Biogeosciences, 14, 1165-1179, https://doi.org/10.5194/bg-14-1165-2017, 2017. 